University of Nebraska - Lincoln

DigitalCommons@University of Nebraska - Lincoln

USDA National Wildlife Research Center - Staff Publications
U.S. Department of Agriculture: Animal and Plant Health Inspection Service

April 2001

\title{
DISEASE EMERGENCE IN BIRDS: CHALLENGES FOR THE TWENTY-FIRST CENTURY
}

\author{
Milton Friend \\ Salton Sea Science Office, U.S. Geological Survey \\ Robert G. McLean \\ National Wildlife Health Center, U.S. Geological Survey \\ F. Joshua Dein \\ National Wildlife Health Center, U.S. Geological Survey
}

Follow this and additional works at: https://digitalcommons.unl.edu/icwdm_usdanwrc

Part of the Environmental Sciences Commons

Friend, Milton; McLean, Robert G.; and Dein, F. Joshua, "DISEASE EMERGENCE IN BIRDS: CHALLENGES FOR THE TWENTY-FIRST CENTURY" (2001). USDA National Wildlife Research Center - Staff Publications. 512.

https://digitalcommons.unl.edu/icwdm_usdanwrc/512

This Article is brought to you for free and open access by the U.S. Department of Agriculture: Animal and Plant Health Inspection Service at DigitalCommons@University of Nebraska - Lincoln. It has been accepted for inclusion in USDA National Wildlife Research Center - Staff Publications by an authorized administrator of DigitalCommons@University of Nebraska - Lincoln. 


\title{
OVERVIEW
}

\section{DISEASE EMERGENCE IN BIRDS: CHALLENGES FOR THE TWENTY-FIRST CENTURY}

\author{
Milton Friend, ${ }^{1}$ Robert G. McLean, ${ }^{2}$ And F. Joshua Dein ${ }^{2,3}$ \\ ${ }^{1}$ Salton Sea Science Office, U.S. Geological Survey, 6006 Schroeder Road, Madison, Wisconsin 53711, USA; and \\ ${ }^{2}$ National Wildlife Health Center, U.S. Geological Survey, 6006 Schroeder Road, Madison, Wisconsin 53711, USA
}

THE PAPER By Hartup et al. (2001) on House Finch (Carpodacus mexicanus) conjunctivitis is an example of the rapid geographic spread that can result from disease emergence in naïve populations. That event was neither novel nor transient relative to its occurrence or effects. Disease emergence and reemergence are hallmarks of the latter part of the twentieth century (Center for Disease Control 1994, Levins et al. 1994, DaSilva and Laccarino 1999, Gratz 1999). Current examples involving domestic animals include the problems in Europe with bovine spongiform encephalopathy (BSE, or "mad cow disease") (Brown 2001) and foot-andmouth disease (FMD) (Kitching 1999). Human health has been affected by diseases caused by an array of viruses (Morse 1993, Nichol et al. 1993, Murphy and Nathanson 1994), bacteria (Dennis 1998, DaSilva and Laccarino 1999), rickettsia (Walker and Dumier 1996, Azad et al. 1997), protozoans (Tuerrant 1997, Saini et al. 2000), and metazoan parasites (Hildreth et al. 1991, Gubler 1998), as well as other causes. Acquired immune deficiency syndrome (AIDS) has received the most notoriety of those diseases (Hahn et al. 2000, Schwartlander et al. 2000). A similar pattern exists on a global scale for free-ranging wildlife populations (Table 1) (Friend 1994, 1995; Epstein et al. 1998, Daszak et al. 2000). However, in comparison to disease emergence affecting humans and domestic animals, response to emerging diseases of wildlife is generally superficial. We present concepts and data to support our contention that failure to adequately address disease emergence in free-ranging wildlife is resulting in a diminished capability to achieve and sustain desired geographic distributions and population abundance for species of wild birds, including some threatened and endangered avifauna.

\footnotetext{
${ }^{3}$ Address correspondence to this author. E-mail: joshua_dein@usgs.gov
}

For clarity, we define disease and disease emergence in the context of our use of those terms because they are the focus of our comments. Disease is any departure from health (Guralnik 1982); that is, dysfunction contributing to physiological, physical, reproductive, behavioral, or other impairment that reduces the probability of survival of individuals. If enough individuals are affected, the collective effects can reduce the sustainability of the population. Although disease can result from exposure to a wide variety of physical, chemical, and biological agents and other conditions, we focus this paper on microbes and parasites and to overt mortality caused by them. Thus, disease effects presented only represent the proverbial "tip of the iceberg" relative to the challenges wild avifauna face from disease. Our perspective of disease emergence expands the earlier definitions of emerging diseases by others (Centers for Disease Control and Prevention 1994, Morse 1995) to include all species. Our comments are defined by the context of disease occurrences that have increased within the past three decades, or threaten to increase in the near future relative to populations affected, geographic distribution, or magnitude of effects.

\section{DisEASE EFFECTS}

Haldane (1949) cited by May (1988) stated ". . . infectious diseases have undoubtedly been the main agents of morbidity and mortality (and thus the dominant selective factors) in human populations at least for the past 10,000 years." Support for the continued dominance of microbes and protozoan and metazoan parasites over humankind can be found in the writings of such notable scholars as McNeill (1976) and Lederberg (1988, 1993, 1997).

It is folly to think that wild birds and other wildlife are less susceptible to the influences of disease than humans and domestic animals. Nevertheless, ". . . ecologists and evolutionary 
biologists virtually ignored parasites [including microbes] until recently, even as a source of mortality for host species [wildlife] of primary interest" (Toft 1991). This is inconsistent with the viewpoints of Price (1980) that "... parasites affect the life and death of practically every other living organism;" and that

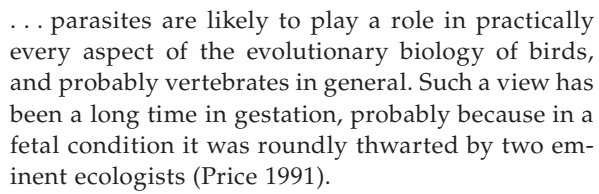

The writings of Elton (1927) and Lack (1954, 1966) and support for their conclusions by other notable ecologists suppressed for decades considerations of disease as a significant factor for avian population dynamics (Price 1991).

More recent evaluations have clearly demonstrated that the emergence of avian malaria (Plasmodium relictum) and avian pox in Hawaii has regulated the geographic distribution and abundance of native Hawaiian forest birds on the Island of Hawaii (Warner 1968, van Riper et al. 1986, Atkinson et al. 1995). Others (Hudson 1986, Hudson and Dobson 1991) have shown that the parasite Trichostrongylus tenuis regulates population numbers of Red Grouse ( $\mathrm{La}$ gopus lagopus scoticus).

The biological significance of Mycoplasma gallisepticum infections in House Finches is equivocal. The Hartup et al. (2001) study did not detect gross differences in survival for diseased and normal finches. However, others have concluded that mycoplasmal conjunctivitis is a significant mortality factor for eastern populations of House Finches and is capable of causing population declines (Luttrell et al. 1998, Nolan et al. 1998, Hochachka and Dhondt 2000). Our purpose is not to debate the merits of different evaluations involving House Finch conjunctivitis. Instead, we note that this new disease for wild birds is a recent addition to the continuum of emerging diseases that are challenging the integrity of avian communities (Table 2).

It is noteworthy that disease challenges for avian communities are occurring in some of the more pristine ecosystems on Earth. For example, it has recently been stated that

the birds of the Galapagos now confront serious problems caused by introduced diseases.... For
Galapagos to survive, increased technical and financial means must be found to defeat the worst of the plagues and to monitor and respond to the threats of these introduced species. (Vargas 2000).

Avian disease has also become an issue in Antarctic penguins. An infectious agent is suspected as the cause for mass mortality in Adelie Penguin (Pygoscelis adelaiae) chicks during the 1990s (Gardner et al. 1997a, b). More recently, antibodies to infectious bursal disease virus (IBDV), a pathogen of domestic chickens (Gallus domesticus), have been found in sera collected from wild Emperor (Aptenodytes forsteri) and Adelie penguins (Gardner et al. 1997a, b). Antibodies to IBDV have also been found in sera of Spectacled Eiders (Somateria fischeri) nesting in a remote area of western Alaska and in nesting Common Eiders (S. mollissima) and Herring Gulls (Larus argentatus) in the Baltic Sea (Hollmén et al. 2000).

Disease emergence.-Disease emergence in avifauna has taken different forms (Table 3), and the frequency of recurrence, geographic spread, species affected, and magnitude of losses following initial events have generally been unpredictable and highly variable. For example, it took only three years from the first reported case of House Finch conjunctivitis in 1994 in the Washington, D.C. area to steadily spread westward to the Mississippi River and essentially occupy the entire eastern range of House Finches (Fischer et al. 1997, Friend 1999a). Other diseases, such as the reovirus responsible for the deaths of moderate numbers of American Woodcock (Scolopax minor), have remained highly localized (Docherty et al. 1994). Only a single recurrence of that reovirus has been documented (Docherty 1999). In contrast, annual losses of substantial numbers of deaths annually of American Coot (Fulica americana) have been caused by the trematode Leyogonimus polyoon (Cole and Friend 1999). Duck plague has spread from the initial 1967 outbreak in wild waterfowl on Long Island, New York (Leibovitz and Hwang 1968), in a haphazard manner across much of the United States and into Canada (Friend 1999b, Converse and Kidd 2001).

Variability also has been great relative to species affected. House Finch conjunctivitis in the wild has essentially been limited to House Finches. Duck plague is a disease limited to Anseriformes (Sandhu and Leibovitz 1997), 
and there is a great deal of variability in the susceptibility for different species of waterfowl (Spieker et al. 1996). In contrast, West Nile virus has been isolated from more than 60 species of dead free-ranging birds and from an additional 20 species of wild birds that have died in zoological and other collections (Steele et al. 2000) since the initial North American appearance of West Nile fever in 1999 (Lanciotti et al. 1999). West Nile virus is also responsible for the deaths of several species of mammals, including humans (Center for Disease Control 1999). The magnitude of bird deaths associated with specific diseases is also highly variable, ranging along a spectrum from individual bird events from chronic diseases of attrition such as avian tuberculosis (Mycobacterium avium), to small numbers of deaths per event for diseases such as renal coccidiosis (Eimeria truncata), to large-scale epizootics such as those caused by West Nile virus and avian cholera (Pasteurella multocida) (Friend and Franson 1999). Avian botulism (Clostridium botulinum type C) and avian cholera currently stand out as major problems because of the magnitude of losses they cause, broad spectrum of species affected, annual frequency of epizootics, and their continually increasing geographic area of occurrence (Table 4) (Friend 1999c, Rocke and Friend 1999). However, it is the cumulative effects of the wide variety of emerging diseases that is of concern, rather than individual disease events or diseases.

Population effects.-The ability to determine and evaluate the effect of disease on the population dynamics of free-ranging avifauna is fraught with difficulties and confounded by a host of factors that complicate the determination of cause-and-effect relationships. As a result, evaluations are primarily at a gross scale and, in the absence of long-term studies on discrete populations or population cohorts, are generally associated with major changes in population numbers, rather than subtle changes such as long-term population depression, reproductive effects, or indirect mortality.

The current decline of vultures on the Indian subcontinent (Holden 2000) is an extreme example of the effects disease can have on avifauna. Over the past three to five years, populations of the Indian White-Backed (Gyps bengalensis) and the Indian Long-Billed (G. indicus) vultures over much of India have fallen to $<5 \%$ of their 
TABLE 2. Examples of disease emergence in wild avifauna.

\begin{tabular}{|c|c|c|c|c|c|}
\hline Agent type & Disease & $\begin{array}{l}\text { Initial } \\
\text { event }\end{array}$ & $\begin{array}{l}\text { Primary taxa } \\
\text { affected }\end{array}$ & $\begin{array}{c}\text { Geographic } \\
\text { location/current } \\
\text { status }\end{array}$ & Citation \\
\hline \multirow[t]{5}{*}{ Virus } & $\begin{array}{l}\text { Duck plague } \\
\text { (Duck virus } \\
\text { enteritis) }\end{array}$ & 1967 & Anatidae & $\begin{array}{l}\text { New York, } \\
\text { USA; spread- } \\
\text { ing since } \\
1970 \text { s } \\
\text { throughout } \\
\text { USA and } \\
\text { Canada. }\end{array}$ & $\begin{array}{l}\text { Converse and Kidd } \\
\text { 2001; Friend } \\
\text { 1999b; Leibovitz } \\
\text { and Hwang 1968; }\end{array}$ \\
\hline & $\begin{array}{l}\text { Newcastle dis- } \\
\text { ease }\end{array}$ & 1990 & Phalacrocoracidae & $\begin{array}{l}\text { Saskatchewan, } \\
\text { Canada; } \\
\text { spreading } \\
\text { since } 1992 \\
\text { within USA } \\
\text { and Canada. }\end{array}$ & $\begin{array}{l}\text { Docherty and Friend } \\
\text { 1999; Glaser et al. } \\
\text { 1999; Meteyer et } \\
\text { al. 1997; Wobeser } \\
\text { et al. } 1990\end{array}$ \\
\hline & West nile fever & 1999 & Corvidae & $\begin{array}{l}\text { New York, } \\
\text { USA; spread- } \\
\text { ing }\end{array}$ & Steele 2000 \\
\hline & Avian poxa & 1978 & Accipitridae & $\begin{array}{l}\text { Alaska, USA; } \\
\text { spread } \\
\text { throughout } \\
\text { USA. }\end{array}$ & $\begin{array}{l}\text { Hansen 1999; Win- } \\
\text { dingstad et al. } \\
1993\end{array}$ \\
\hline & $\begin{array}{l}\text { Woodcock reo- } \\
\text { virus }\end{array}$ & 1989 & Scolopacidae & $\begin{array}{l}\text { New Jersey, } \\
\text { Virginia, } \\
\text { USA; quies- } \\
\text { cent since } \\
\text { second event. }\end{array}$ & Docherty et al. 1994 \\
\hline \multirow[t]{6}{*}{ Bacteria } & Avian cholera & 1944 & Anatidae & $\begin{array}{l}\text { California, Tex- } \\
\text { as, USA; } \\
\text { spread across } \\
\text { USA and into } \\
\text { Canada since } \\
\text { 1970s. }\end{array}$ & Friend $1999 \mathrm{c}$ \\
\hline & Mycoplasmosis & 1994 & Fringillidae & $\begin{array}{l}\text { District of Co- } \\
\text { lumbia, USA; } \\
\text { spread } \\
\text { throughout } \\
\text { entire eastern } \\
\text { range of } \\
\text { House Finch. }\end{array}$ & Fischer et al. 1997 \\
\hline & $\begin{array}{l}\text { Avian tubercu- } \\
\text { losis }\end{array}$ & 1986 & Gruidae & $\begin{array}{l}\text { New Mexico, } \\
\text { USA; sporad- } \\
\text { ic cases in } \\
\text { other avian } \\
\text { species. }\end{array}$ & $\begin{array}{l}\text { Snyder et al. 1991; } \\
\text { Friend 1999c }\end{array}$ \\
\hline & Salmonellosis & $1980 \mathrm{~s}$ & Fringillidae & $\begin{array}{l}\text { Various, USA; } \\
\text { increasing in } \\
\text { USA and } \\
\text { Canada. }\end{array}$ & $\begin{array}{l}\text { Friend 1999e; Na- } \\
\text { tional Wildlife } \\
\text { Health Center } \\
2001\end{array}$ \\
\hline & $\begin{array}{l}\text { Avian botulism } \\
\text { (type C in } \\
\text { fish-eating } \\
\text { birds) }\end{array}$ & 1996 & Pelecanidae & $\begin{array}{l}\text { California, } \\
\text { USA; annual } \\
\text { occurrence at } \\
\text { Salton Sea. }\end{array}$ & $\begin{array}{l}\text { National Wildlife } \\
\text { Health Center } \\
2001\end{array}$ \\
\hline & $\begin{array}{l}\text { Avian } \\
\text { Botulism } \\
\text { (type C, clas- } \\
\text { sical) }\end{array}$ & $1890 \mathrm{~s}^{\mathrm{b}}$ & Anatidae & $\begin{array}{l}\text { California, } \\
\text { Utah, USA; } \\
\text { Nationwide } \\
\text { expansion } \\
\text { within USA } \\
\text { since 1980s } \\
\text { and increas- } \\
\text { ing problem } \\
\text { in Canada } \\
\text { and Mexico. }\end{array}$ & $\begin{array}{l}\text { Kalmback 1968; } \\
\text { Rocke and Friend } \\
1999\end{array}$ \\
\hline
\end{tabular}


TABle 2. Continued.

\begin{tabular}{|c|c|c|c|c|c|}
\hline Agent type & Disease & $\begin{array}{l}\text { Initial } \\
\text { event }\end{array}$ & $\begin{array}{l}\text { Primary taxa } \\
\text { affected }\end{array}$ & $\begin{array}{c}\text { Geographic } \\
\text { location/current } \\
\text { status }\end{array}$ & Citation \\
\hline Bacteria & $\begin{array}{l}\text { Necrotic enteri- } \\
\text { tis }\end{array}$ & 1982 & Anatidae & $\begin{array}{l}\text { Wisconsin, Illi- } \\
\text { nois, USA; } \\
\text { events fol- } \\
\text { lowed in } \\
\text { Canada and } \\
\text { other areas of } \\
\text { USA. }\end{array}$ & $\begin{array}{l}\text { Siegfried and Brand } \\
\text { 1982; Wobeser and } \\
\text { Rainnie } 1987\end{array}$ \\
\hline Fungi & Mycotoxicosis & 1982 & Gruidae & $\begin{array}{l}\text { Texas, USA; lo- } \\
\text { calized occa- } \\
\text { sional occur- } \\
\text { rences. }\end{array}$ & $\begin{array}{l}\text { Windingstad et al. } \\
1989\end{array}$ \\
\hline $\begin{array}{l}\text { Metazoan para- } \\
\text { site }\end{array}$ & Trematodiasis & 1996 & Rallidae & $\begin{array}{l}\text { Wisconsin, } \\
\text { USA; local- } \\
\text { ized annual } \\
\text { occurrences. }\end{array}$ & Cole and Friend 1999 \\
\hline
\end{tabular}

a Example is specific for avian pox in Bald Eagles; in general avian pox is occurring with increased frequency in several groups of birds including Anatidae and Fringillidae in addition to occurrences in Hawaii affecting Depanididae.

${ }^{\mathrm{b}}$ Avian botulism first appeared as a major killer of waterbirds in the late 1890 s to early 1900 s; for the next 40 years that disease, with rare exception, was only reported to occur west of the Mississippi River (Kalmback 1968).

former abundance. Pathological findings strongly suggest the cause to be a disease of viral etiology (Rahmani and Prakash 2000). That disease has also reached Pakistan and Nepal, and may be the cause for the decline in vulture populations in other parts of Asia.

Common Eider populations in the Gulf of Finland are declining at a rate of 6 to $10 \%$ yearly (Hario 1998). Disease emergence is postulated to be the cause for the recent decline. In the late 1980s, duckling survival dropped to 1 to $5 \%$ in some areas and mortality events have killed large numbers of young and some adult eiders (Hollmén et al. 1999, 2000). A high prevalence of antibodies to IBDV has been found in the blood of eiders nesting within the Gulf of Finland. Those findings are of concern because IBDV causes substantial mortality in chickens (Hollmén et al. 2000). In addition, two viruses other than IBDV have been isolated from Gulf of Finland eiders. Investigations are ongoing relative to the role of those viruses in the eider decline (T. Hollmén pers. comm.).

Emerging diseases can have added significance when they appear in avian populations already in decline or when threatened and endangered species are affected because of low population numbers associated with those status categories. During 1996, a single event of type $C$ avian botulism was responsible for the loss of an estimated 15 to $20 \%$ of the western population of White Pelicans (Pelacanus ery- throrhynchos). This subpopulation has been in decline for several decades (D. Anderson pers. comm.). Substantial numbers of endangered California Brown Pelican (Pelacanus occidentalis) also died during that event. Despite the near global occurrence for type C avian botulism (Eklund and Dowell 1987), large-scale mortality of fish-eating birds from type $\mathrm{C}$ toxin is without precedent. The situation occurring at the Salton Sea in California appears to involve disease emergence in the form of an aberrant disease cycle for this environmental disease. Since 1996, type C avian botulism has been an annual cause of pelican mortality at the Salton Sea.

The Northern Pintail (Anas acuta) is another species whose population levels within North America are being affected by disease. In 1957, the estimated breeding population for that species exceeded 10 million, but then steadily declined to $\sim 3.5$ million by 1964 , and after eventually increasing back to $\sim 7$ million in 1972 , declined again to a low of slightly above 2 million in 1991 (Wilkins and Cooch 1999). Despite years of major efforts focused on restoring that species, the breeding population in 1999 was $30 \%$ below the long-term average and well below the long-term goal (Wilkins and Cooch 1999). The continued suppression of Northern Pintail populations is not surprising given the fact that the Northern Pintail is often the dominant species in major mortality events from 
TABLE 3. Forms of disease emergence in wild birds.

\begin{tabular}{|c|c|c|}
\hline Event characterization & Description & Example \\
\hline New disease & $\begin{array}{l}\text { First appearance in wild } \\
\text { birds within geographic } \\
\text { area (region, nation). }\end{array}$ & $\begin{array}{l}\text { House Finch conjunctivitis (Fischer et } \\
\text { al. 1997; Hartup et al. 2001) }\end{array}$ \\
\hline Geographic expansion & $\begin{array}{l}\text { Movement of an enzootic } \\
\text { disease of birds beyond } \\
\text { the geographic boundar- } \\
\text { ies of historic and com- } \\
\text { mon occurrence. }\end{array}$ & Avian cholera (Friend 1999c) \\
\hline Reemergence $^{a}$ & $\begin{array}{l}\text { Recurrence of a dormant } \\
\text { disease of wild birds in } \\
\text { similar or the same spe- } \\
\text { cies and within the histor- } \\
\text { ic geographic boundaries } \\
\text { for previous disease activ- } \\
\text { ity. }\end{array}$ & $\begin{array}{l}\text { Velogenic Newcastle disease in Double- } \\
\text { crested Cormorants (Phalacrocorax au- } \\
\text { ritus) (Glaser et al. 1991) }\end{array}$ \\
\hline Novel appearance & $\begin{array}{l}\text { Occurrence of a disease of } \\
\text { birds in species that it } \\
\text { does not normally affect. }\end{array}$ & $\begin{array}{l}\text { Type } C \text { avian botulism in pelicans (T. } \\
\text { Rocke unpubl. data; National Wildlife } \\
\text { Health Center 2001) }\end{array}$ \\
\hline
\end{tabular}

${ }^{a}$ Reemergence can lead to geographic expansion as has occurred for Newcastle disease.

avian botulism and avian cholera (Ball et al. 1998, Miller and Duncan 1999, National Wildlife Health Center 2001). Those events occur from their Canadian breeding grounds to wintering areas in the southern United States and Mexico. Heavy fall and spring losses also occur within the United States during some years. During 1997, an estimated 1.5 million water birds, primarily waterfowl (the majority of those birds being Northern Pintails) died from avian botulism during two sequential events. The first occurred in Canada and the other on the marshes in the vicinity of the Great Salt Lake in Utah (Ball et al. 1998).

The Whooping Crane (Grus americana) serves as our final example of disease effects on avian populations. A foster parenting project was undertaken to establish an additional migratory flock of Whooping Cranes in the western United States (Drewien and Bizean 1978). The flock peaked at 32 birds and then declined rapidly. Approximately 39\% of the Whooping Cranes found dead from that flock died from, or were infected and would have died from, avian tuberculosis (Snyder et al. 1991). Typically, $<1 \%$ of wild birds received for necropsy are diagnosed with avian tuberculosis (Smit et al. 1987, Converse and Dein 1991, Friend 1999d). Avian tuberculosis was clearly a major factor in the failure of the Whooping Crane foster parenting project.

Zoonoses.-It should also be recognized that wild birds are involved in the dissemination and transmission of a variety of diseases of humans (zoonoses) and domestic animals. Harris (1991) and Cooper (1990) list 24 and 22 zoonoses, respectively, involving wild birds. West Nile virus is the latest zoonosis involving birds to appear in the United States. Other zoonoses involving wild birds are also gaining prominence as disease issues. During recent years, salmonellosis (Salmonella typhymerium) has gained international importance as a major killer of birds at feeding stations (Kirkwood and MacGregor 1998, Friend 1999e). It is likely that this situation is an emerging example of problems that will continue to develop due to an increased dependency upon urban and suburban habitats and feeding stations as a result of the diminished base of natural habitat for many species of birds. The enhanced interface between humans and wild birds in the urban and suburban landscape presents increased opportunities for disease transfer to humans. This issue is a focus for growing concerns among some segments of society relative to urban populations of wild waterfowl, primarily Canada Geese (Branta canadensis) (Graczyk et al. 1998, Saltoun et al. 2000).

\section{DISCUSSION}

The importance of disease emergence for human society is of international scope and has stimulated the development of a wide variety of projects, collaborative efforts, scientific publi- 
TABLE 4. Examples of single event losses of wild birds due to avian botulism (Clostridium botulinum type C) and avian cholera (Pasteurella multocida).

\begin{tabular}{|c|c|c|c|}
\hline Year & Geographic location & Primary taxa affected ${ }^{a}$ & Losses $^{\mathrm{b}}$ \\
\hline \multicolumn{4}{|c|}{ Avian botulism } \\
\hline 1980 & $\begin{array}{l}\text { Utah, USA (Bear River Marshes, } \\
\text { Box Elder Co.) }\end{array}$ & Anatidae & $105,000^{c}$ \\
\hline 1982 & $\begin{array}{l}\text { Caspian Sea, Russia (Guryev } \\
\text { Region, Kazachstan) }\end{array}$ & Anatidae & $1,000,000^{\mathrm{d}}$ \\
\hline 1995 & Alberta, Canada (Pakowki Lake) & Anatidae & $(>100,000)^{\mathrm{e}}$ \\
\hline 1996 & $\begin{array}{l}\text { Saskatchewan, Canada (Old } \\
\text { Wives Lake) }\end{array}$ & Anatidae & $134,000^{\mathrm{e}}$ \\
\hline 1997 & $\begin{array}{l}\text { Saskatechwan, Canada (Old } \\
\text { Wives Lake) }\end{array}$ & Anatidae & $1,000,000^{\mathrm{e}}$ \\
\hline 1997 & $\begin{array}{l}\text { Utah, USA (Bear River Marshes, } \\
\text { Box Elder Co.) }\end{array}$ & Anatidae & $500,000^{e}$ \\
\hline \multicolumn{4}{|c|}{ Avian cholera } \\
\hline 1970 & $\begin{array}{l}\text { Maryland, USA (Chesapeake } \\
\text { Bay) }\end{array}$ & Anatidae & $88,000^{\mathrm{f}, \mathrm{g}}$ \\
\hline 1978 & $\begin{array}{l}\text { Maryland, USA (Chesapeake } \\
\text { Bay) }\end{array}$ & Anatidae & $(31,295)^{\mathrm{h}}$ \\
\hline 1980 & $\begin{array}{l}\text { Nebraska, USA (Rainwater Ba- } \\
\text { sins) }\end{array}$ & Anatidae & $80,000^{\mathrm{c}, \mathrm{i}}$ \\
\hline 1982 & $\begin{array}{l}\text { Nebraska, USA (Rainwater Ba- } \\
\text { sins) }\end{array}$ & Anatidae & $32,800-36,300^{j}$ \\
\hline 1995 & $\begin{array}{l}\text { Northwest Territories, Canada } \\
\text { (Egg River Colony, Banks Is- } \\
\text { land) }\end{array}$ & Anatidae & $30,000^{\mathrm{k}}$ \\
\hline 1998 & $\begin{array}{l}\text { Utah, USA (Great Salt Lake, Salt } \\
\text { Lake Co.) }\end{array}$ & $\begin{array}{l}\text { Podicipedidae, Ana- } \\
\text { tidae }\end{array}$ & $50,000^{c}$ \\
\hline
\end{tabular}

a Although Anatidae is the primary taxa affected by avian botulism, large numbers of shorebirds (Scolopacidae), American Coot (Rallidae) and Recorvirostridae (American Avocets, Recurvirostra americana, and Black-Necked Stilts, Himantopus mexicanus) also commonly die during avian botulism epizootics.

${ }^{\mathrm{b}}$ Estimated losses and (carcasses retrieved $=$ minimum losses).

c Data from U.S. Geological Survey, National Wildlife Health Center Epizootiology Database.

d Kuznetsov 1992.

e Ball et al. 1998.

${ }^{\mathrm{f}}$ National Wildlife Federation 1970.

g Locke et al. 1970.

${ }^{\mathrm{h}}$ Montgomery et al. 1980 .

i Brand 1984.

i Hurt et al. 1983.

${ }^{k}$ Samuel et al. 1999

cations, and reports and other actions focused on combating that problem on behalf of human health. The economic effects of emerging diseases such as BSE and FMD are enormous and demand aggressive efforts to combat the emergence of not only those diseases, but also other emerging diseases that threaten the products of agriculture needed to provide food and fiber for a continually expanding human population and global economy.

We have provided testimony of the biological effects for avifauna of emerging disease, a situation that also extends to other species and groups of free-ranging wildlife. Our testimony deals only with the tip of the iceberg rather than the full effect of disease emergence. The true cost from disease is associated with the chronic attrition that occurs from the broad spectrum of diseases present, rather than from the high-visibility events that generate media attention and transient crisis responses from the conservation community. In addition, the magnitude of losses from some disease events can be of sufficient severity to challenge the ability of already diminished avian populations to overcome those single-event losses.

If disease emergence is not aggressively addressed on behalf of avifauna, the resulting effects will extend beyond the biological to social and economic losses as well. Consider for example the potential effects of significant reductions of scavenger species such as vultures in India and crows in the United States on the removal of carcasses; revenue lost from ecotour- 
ism and sport hunting due to declines in bird populations; and the influence on cultural relations and social needs of native peoples.

The primary causes for the emergence of diseases affecting humans are generally agreed upon and provide a focus for corrective actions (Centers for Disease Control and Prevention 1994, Morse 1995, Wilson 1995, DaSilva and Laccarino 1999). Many of the same factors are involved for disease emergence in free-ranging wildlife. However, neither the avian nor greater conservation communities are responding to disease emergence in a manner consistent with the biological significance of that threat, or with the ecological understanding of how to approach that problem. Successful disease prevention and control for free-ranging wildlife requires that the approaches used are based on the fact that disease is an outcome, rather than a cause. Environmental conditions are often a basic cause associated with disease emergence, persistence, and spread, and must be addressed to successfully combat disease. Thus, two of the barriers inhibiting adequate response to disease emergence in avian and other wildlife species are (1) the persistence of perspectives that disease is not a significant factor relative to the population dynamics of wild species; and (2) a tendency to focus on the affected species or the causative organism rather than on the affected environment.

Aldo Leopold (1933) spoke to the issue of disease control in his classic treatise Game Management by stating that treatment of afflicted animals was a recessive approach. He further noted that ". . . the real determinants of disease mortality are the environment and the population," both of which are being "doctored daily, for better or for worse, by gun and axe, and by fire and plow." The wisdom of Leopold (1933) regarding disease has even greater relevance today. Continued landscape changes due to demands for human living space and other basic needs will continue to alter the geographic distribution and aggregation of avifauna in a manner likely to facilitate disease emergence and spread among wild birds. Reductions in the habitat base for avian species due to landscape changes challenges the ability to sustain population levels that can withstand major effects from disease and still provide the collective values human society seeks from wild birds.
Human behavior is additionally an important barrier inhibiting adequate response to disease emergence in wild birds. This factor is complex and is beyond the scope of this paper, other than to note that major differences afforded disease-control efforts for humans and domestic animals are personal ownership and economic influences. Wildlife in the United States and in many other countries is held in trust by government agencies with stewardship responsibilities for various species. Therefore, the public does not have the same incentives that have resulted in the development of major programs and industries to address disease in humans and domestic animals. The common ownership of wildlife by others (government) contributes to a detached perspective and approach to disease that is, in part, a variation on The Tragedy of the Commons (Hardin 1968) and, in part, laissez-faire, except for transient crisis responses.

We have provided a perspective towards disease that may challenge personal viewpoints of others involved in the conservation of wild birds. Our intent is to stimulate reexamination of the importance of disease on behalf of our avian resources. We strongly believe that due to landscape changes that have already occurred, and those certain to occur in the near future, a proactive, rather than a reactive, approach towards disease is required to discharge our stewardship obligations. Approximately 40 to $50 \%$ of land on the Earth has been irreversibly transformed or degraded by human actions. An additional one-third of global land cover will be transformed over the next 100 years (Ayensu et al. 2000). Human-induced changes in biotic diversity and alterations in the structure and function of ecosystems are the two most dramatic ecological trends of the past century (Vitousek et al. 1997). The consequences of these changes are that society must now discharge a role of perpetual stewardship to maintain components and functions that once constituted the natural processes at the time Lack (1954, 1966) and others were making their judgments about the role of disease. Combating emerging disease has now become one of the adjustments that must be made to repair ecological integrity in a manner that sustains avian biodiversity and desired levels of avian populations. 


\section{Literature Cited}

Atkinson, C., K. L. Woods, R. J. Dusek, L. S. Sileo, AND W. M. IKO. 1995. Wildlife disease and conservation in Hawaii: Pathogenicity of avian malaria (Plasmodium relictum) in experimentally infected Iiwi (Vestiaria coccinea). Parasitology 111 (Supplement):59-69.

Ayensu, E., D. Van R. Claasen, M. Collins, A. Dearing, L. Fresco, M. GadgIL, AND H. Gitay. 1999. International ecosystem assessment. Science 286:685-686.

Azad, A. F., S. Radulovic, J. A. Higgins, B. H. NoDEN, AND J. M. TROYER. 1997. Flea-borne rickettsioses: Ecological considerations. Emerging Infectious Diseases 3:319-327.

Balazs, G. H., ANd S. G. PoOley, Eds. 1991. Research plan for marine turtle fibropapiloma. U.S. Department of Commerce, National Oceanographic and Atmospheric Administration, Natural Marine Fisheries Service. NOAA-TMNMFS-SWFSC-156.

Ball, G., T. Bollinger, M. Conly, J. Kadlec, B. Macfarlane, H. Murkin, T. Murphy, M. Pybus, T. Rocke, M. Samuel, D. Sharp, and G. WobeSER. 1998. Report to the Prairie Habitat Joint Venture by the working group on avian botulism. Canadian Cooperative Wildlife Health Centre, Saskatoon, Saskatchewan.

BENGIS, R. G., AND D. F. KEET. 2000. Bovine tuberculosis in the Kruger National Park. Pages 14-18 in Abstracts 49th Annual Wildlife Disease Association Conference.

Berger, M. L., R. Speare, P. Daszak, D. E. Green, AND A. CUNNINGHAM. 1998. Chrytridiomycosis causes amphibian mortality associated with population declines in the rain forests of Australia and Central America. Proceedings of the National Academy of Sciences USA 95:9031-9036.

BRAND, C. J. 1984. Avian cholera in the Central and Mississippi flyways during 1979-80. Journal of Wildlife Management 48:399-406.

Brouder, M. J., AND T. L. HoffNAgle. 1997. Distribution and prevalence of the Asian fish tapeworm, Bothriocephalus acheilognathi, in the Colorado River and tributaries, Grand Canyon, Arizona, including two new host records. Journal of the Helminthological Society of Washington 64:219-226.

Brown, P., R. G. Will, R. Bradley, D. M. Asher, AND L. DetwiLer. 2001. Bovine Spongiform Encephalopathy and Variant Creutzfeldt-Jakob Disease: Background, evolution, and current concerns. Emerging Infectious Diseases 7:16-17.

Center for Disease Control. 1999. Outbreak of West Nile-like viral encephalitis-New York, 1999. Morbidity and Mortality Weekly Report 48:845-849.
Centers for Disease Control and Prevention. 1994. Addressing Emerging Infectious Disease Threats: A Prevention Strategy for the United States. U.S. Department of Health and Human Services, Public Health Service, Atlanta, Georgia.

Cole, R. A., AND M. Friend. 1999. Miscellaneous parasitic diseases. Pages 249-262 in Field Manual of Wildlife Diseases (M. Friend and J. C. Franson, Eds.). U.S. Geological Survey, Biological Resources Division, National Wildlife Health Center, Madison, Wisconsin.

Converse, K. A., AND F. J. DeIn. 1991. Tuberculosis in wild birds: Implications for captive birds. Page 140 in Proceedings of the American Association of Zoo Veterinarians (R. Cambre, Ed.). AAZV, Media, Pennsylvania.

Converse, K. A., AND G. A. KIDD. 2001. Duck plague epizootics in the United States, 1967-1995. Journal of Wildlife Diseases 37:347-357.

Cooper, J. E. 1990. Birds and zoonoses. Ibis 132:181191.

DaSilva, E., AND M. Laccarino. 1999. Emerging diseases: A global threat. Biotechnology Advances 17:363-384.

Daszak, P., A. A. Cunningham, and A. D. Hyatt. 2000. Emerging infectious disease of wildlifeThreats to biodiversity and human health. Science 287:443-449.

DENNIS, D. T. 1998. Epidemiology, ecology and prevention of Lyme disease. Pages 7-34 in Lyme Disease (D. W. Rahn and J. Evans, Eds.). American College of Physicians, Philadelphia.

Docherty, D. E. 1999. Woodcock reovirus. Pages 185-192 in Field Manual of Wildlife Diseases (M. Friend and J. C. Franson, Eds.). U.S. Geological Survey, Biological Resource Division, National Wildlife Health Center, Madison, Wisconsin.

Docherty, D. E., K. A. Converse, W. R. Hansen, AND G. W. Norman. 1994. American Woodcock (Scolopax minor) mortality associated with reovirus. Avian Diseases 38:899-904.

Docherty, D. E., AND M. Friend. 1999. Newcastle disease. Pages 175-179 in Field Manual of Wildlife Diseases (M. Friend and J. C. Franson, Eds.). U.S. Geological Survey, Biological Resources Division, National Wildlife Health Center, Madison, Wisconsin.

Drewien, R. C., and E. G. Bizean. 1978. Cross-fostering Whooping Cranes to sandhill foster parents. Pages 201-222 in Endangered Birds: Management Techniques for Preserving Threatened Species (S.A. Temple, Ed.). University of Wisconsin Press, Madison.

EKLund, M. W., AND V. R. Dowell. 1987. Avian Botulism-An International Perspective. Charles C. Thomas, Springfield, Illinois.

Elton, C. 1927. Animal Ecology. MacMillan, New York. 
Epstein, P. R., B. Sherman, E. Spanger-Siegfried, A. LANGSTON, S. PRASAD, AND B. McKay. 1998. Marine ecosystems: Emerging diseases as indicators of change. Center for Health and Global Environment, Harvard Medical School, Boston.

Fischer, J. R., D. E. Stallknecht, M. P. Luttrell, A. A. Dhondt, And K. A. Converse. 1997. Mycoplasma conjunctivitis in wild songbirds: The spread of a new contagious disease in a mobile host population. Emerging Infectious Diseases 3:69-72.

FRIEND, M. 1994. Diseases of wildlife: Changing patterns and emerging trends. Pages 70-77 in International Wildlife Rehabilitation Council Conference Proceedings. Suisin City, California.

FRIEND, M. 1995. Increased avian diseases with habitat change. Pages 401-403 in Our Living Resources: A Report to the Nation on the Distribution, Abundance, and Health of U.S. Plants, Animals, and Ecosystems (E. T. LaRoe, G. S. Farris, C. E. Puckett, P. D. Doran, and M. J. Mac, Eds.). U.S. Department of the Interior, National Biological Service, Washington, D.C.

FrIEND, M. 1999a. Mycoplasmosis. Pages 115-119 in Field Manual of Wildlife Diseases (M. Friend and J. C. Franson, Eds.). U.S. Geological Survey, Biological Resource Division, National Wildlife Health Center, Madison, Wisconsin.

Friend, M. 1999b. Duck plague. Pages 141-152 in Field Manual of Wildlife Diseases (M. Friend and J. C. Franson, Eds.). U.S. Geological Survey, Biological Resources Division, National Wildlife Health Center, Madison, Wisconsin.

Friend, M. 1999c. Avian cholera. Pages 75-92 in Field Manual of Wildlife Diseases (M. Friend and J. C. Franson, Eds.). U.S. Geological Survey, Biological Resources Division, National Wildlife Health Center, Madison, Wisconsin.

Friend, M. 1999d. Avian tuberculosis. Pages 93-98 in Field Manual of Wildlife Diseases (M. Friend and J. C. Franson, Eds.). U.S. Geological Survey, Biological Resources Division, National Wildlife Health Center, Madison, Wisconsin.

Friend, M. 1999e. Salmonellosis. Pages 99-109 in Field Manual of Wildlife Diseases (M. Friend and J. C. Franson, Eds.). U.S. Geological Survey, Biological Resources Division, National Wildlife Health Center, Madison, Wisconsin.

Friend, M., AND J. C. Franson, EdS. 1999. Field Manual of Wildlife Diseases. U.S. Geological Survey, Biological Resource Division, National Wildlife Health Center, Madison, Wisconsin.

Fryer, J. L., C. N. LANNAN, S. J. GIOVANNONI, AND N. D. Wood. 1992. Priscirickettsia Salmonis gen. nov., sp. nov., the causative agent of an epizootic disease in salmonid fishes. International Journal of Systematic Bacteriology 42:120-126.

Gardner, H., S. Brouwer, L. Gleeson, K. Kerry, AND M. RIDDLE. 1997a. Poultry virus infection found in Antarctic penguins. Penguin Conservation 10:8-21.

Gardner, H., K. KNOWles, M. Riddle, S. Brouwer, AND L. GLEESON. 1997b. Poultry virus infection in Antarctic penguins. Nature 387:245.

Glaser, L. C., I. K. BARKer, D. V. C. WeSELOH, J. LudWIG, R. M. WindingSTAD, D. W. KEY, AND T. K. BOLLINGER. 1999. The 1992 epizootic of Newcastle disease in Double-crested Cormorants in North America. Journal of Wildlife Diseases 35: 319-330.

GraczyK, T. K., R. Fayer, J. M. Trout, E. J. LeWis, C. A. Farley, I. Sulaiman, AND A. A. Lal. 1998. Giardia sp. cysts and infectious Cryptosporidium paroum oocysts in the feces of migratory Canada Geese (Branta canadensis). Applied and Environmental Microbiology 64:2736-2738

GratZ, N. G. 1999. Emerging and resurging vectorborne diseases. Annual Review of Entomology 44:51-75.

GuBLER, D. J. 2001. Resurgent vector-borne diseases as a global health problem. Emerging Infectious Diseases 4:442-450.

GuERRANT, R. L. 1997. Cryptosporidiosis: An emerging highly infectious threat. Emerging Infectious Diseases 3:51-57.

GuRALNIK, D. B., ED. 1982. Webster's New World Dictionary, 2nd college ed. Simon and Schuster, New York.

HaHN, B. H., G. M. SHAW, K. M. DE COCK, AND P. M. SHARP. 2000. AIDS as a zoonosis: Scientific and public health implications. Science 287:607-614.

HalDANE, J. B. S. 1949. Disease and evolution. La Ricerca Science Supplement 19:68-76.

HANSEN, W. 1999. Avian pox. Pages 163-169 in Field Manual of Wildlife Diseases (M. Friend and J. C. Franson, Eds.). U.S. Geological Survey, Biological Resources Division, National Wildlife Health Center, Madison, Wisconsin.

Hardin, G. 1968. The tragedy of the commons. Science 162:1243-1248.

HARIO, M. 1998. Recent trends and research results for four archipelago bird species-Common Eider, Velvet Scoter, Herring Gull and Lesser Black-backed Gull. Pages 12-24 in The Yearbook of the Linnut Magazine (T. Solonen and E. Lammi, Eds.). Bird Life Finland, Kuopio, Finland.

Hartur, B. K., J. M. Bickal, A. A. DhOndt, D. H. LeY, AND G. V. Kollias. 2001. Dynamics of conjunctivitis and Mycoplasma gallisepticum. Auk 118:327-333.

HARRIS, J. M. 1991. Zoonotic diseases of birds. Veterinary Clinics of North America: Small Animal Practice 21:1289-1297.

Hayes, R. L., AND T. J. Goreau. 1990. The tropical coral reef ecosystem as a harbinger of global warming. World Resources Review 3:306-322.

Hildreth, M. B., M. D. JoHnSON, AND K. R. KAZACOs. 1991. Echinococcus multilocularis: A zoonosis 
of increasing concern in the United States. Continuing Education Article \#1. Special Focus Parasitology. The Compendium 13:727-738.

HochachKa, W. M., AND A. A. DHONDT. 2000. Density-dependent decline of host abundance resulting from a new infectious disease. Proceedings of the National Academy of Sciences USA 97:5303-5306.

HoldEN, C. 2000. India's vultures declining. Science 289:1679.

Hollmén, T., J. C. Franson, D. E. Docherty, M. KILPi, M. Hario, L. H. Creekmore, and M. R. PeTERSEN. 2000. Infectious bursal disease virus antibodies in eider ducks and Herring Gulls. Condor 102:688-691.

HOllmén, T., J. T. LeHTONEN, S. SANKARI, T. SOVERI, AND M. HARIO. 1999. An experimental study on the effects of polymorphisms in Common Eider ducklings. Journal of Wildlife Diseases 35:466473.

HuDSON, P. J. 1986. The effect of a parasitic nematode on the breeding production of Red Grouse. Journal of Animal Ecology 55:85-92.

Hudson, P. J., AND A. P. DoBson. 1991. The direct and indirect effects of the caecal nematode Trichostrongylus tenuis on Red Grouse. Pages 4968 in Bird-Parasite Interactions. Ecology, Evolution and Behaviour (J. E. Loye and M. Zuk, Eds.). Oxford University Press, Oxford.

Hurt, J., A. TROUT, AND R. WASHTAK. 1983. History of avian cholera in central Nebraska. Pages 2-10 in Transactions of the April 28-29, 1983, Avian Cholera Advisory Committee (C. Sowards, Ed.). U.S. Fish and Wildlife Service, Pierre, South Dakota.

JACOBSON, E. R., J. M. GASKIN, M. B. BROWN, R. K. Harris, C. H. Gardiner, L. Lapointe, H. P. ADAMS, AND C. RegGiaRdo. 1991. Chronic upper respiratory tract disease of free-living desert tortoises. Journal of Wildlife Diseases 27:296316.

KalmbaCH, E. R. 1968. Type C botulism among wild birds-A historical sketch. U.S. Department of the Interior, Fish and Wildlife Service, Bureau of Sport Fisheries and Wildlife. Special Scientific Report-Wildlife No. 110, Washington, D.C.

Kennedy, S., T. Kuiken, P. D. Jepson, R. Dequitte, M. Forsyth, T. BARRETT, M. W. G. VAN DE BILDT, A. D. M. E. Osterhaus, T. Eybatov, C. Duck, A. Kydyemanov, I. Mitrofanov, and S. Wilson. 2000. Mass die-off of Caspian seals caused by canine distemper virus. Emerging Infectious Disease 6:637-639.

KirKWOOD, J. K., AND S. K. MACGREGOR. 1998. Salmonellosis in provisioned free-living Greenfinches (Carduelis chloris) and other garden birds. Pages 229-234 in European Association of Zoo and Wildlife Veterinarians and BVZS 2nd Sci- entific meeting. (P. Zwart, Ed.). Bunnik, The Netherlands.

KITCHING, R. P. 1999. Foot-and-mouth disease: Current world situation. Vaccine 17:1772-1774.

KuZnetsov, E. A. 1992. Botulism in wild waterfowl in the USSR. Pages 112-122 in Diseases and Parasites of Wild Animals (In Russian). Ministry of Ecology and Natural Resources of Russia, Moscow.

LACK, D. 1954. The Natural Regulation of Animal Numbers. Clarendon Press, Oxford.

LACK, D. 1966. Population Studies of Birds. Oxford University Press, London.

Lanciotti, R. S., J. T. Roehring, V. Deubel, J. Smith, M. Parker, K. Steele, et Al. 1999. Origin of the West Nile virus responsible for an outbreak of encephalitis in the northeastern United States. Science 286:2333-2337.

Laurance, W. F., K. R. McDonald, And R. SPEARE. 1996. Epidemic disease and the catastrophic decline of Australian rain forest frogs. Conservation Biology 10:406-413.

LEDERBERG, J. 1988. Medical science, infectious diseases and the unity of humankind. Journal of the American Medical Association 260:684-685.

LEDERBERG, J. 1993. Viruses and humankind: Intracellular symbiosis and evolutionary competition. Pages 3-9 in Emerging Viruses (S. S. Morse, Ed.). Oxford University Press, New York.

LEDERBERG, J. 1997. Infectious disease as an evolutionary paradigm. Emerging Infectious Diseases 3:414-423.

LeIBOVITZ, L., AND J. HwANG. 1968. Duck plague in American Anseriformes. Bulletin of the Wildlife Disease Association 4:13-14.

LeOpold, A. 1933. Game Management. Charles Scribner's Sons, New York.

LeVINS, R., T. AWERBUCH, U. BRINKMANN, I. ECKardt, P. Epstein, N. Makhoul, C. A. De Possas, C. Puccia, A. Spielman, and M. E. Wilson. 1994. The emergence of new diseases-Lessons learned from the emergence of new diseases and the resurgence of old ones may help us prepare for future epidemics. American Scientist 82:5260.

LOCKE, L. N., V. STOtTS, AND G. WOLFHARD. 1970. An outbreak of fowl cholera in waterfowl on the Chesapeake Bay. Journal of Wildlife Diseases 6: 404-407.

LutTrell, M. P., D. E. Stallknecht, J. R. Fischer, C. T. SEWell, AND S. H. KLEven. 1998. Natural Mycoplasma gallisepticum infection in a captive flock of House Finches. Journal of Wildlife Diseases 34:289-296.

Mamaev, L. V., I. K. G. Visser, S. I. Belikov, N. N. Denikina, T. Harder, M. L. Goatley, B. Rima, B. Edginton, A. D. M. E. Osterhaus, and T. BARRET. 1996. Canine distemper virus in Lake 
Baikal seals (Phoca sibirica). Veterinary Record 138:437-439.

MAY, R. M. 1988. Conservation and disease. Conservation Biology 2:28-30.

McNeILl, W. H. 1976. Plagues and Peoples. Anchor Books/Doubleday, New York.

Meteyer, C. U., D. E. Docherty, L. C. Glaser, J. C. F. Franson, D. A. SenNe, AND R. DunCAN. 1997. Diagnostic findings in the 1992 epornitic or neurotropic velogenic Newcastle disease in Doublecrested Cormorants from the upper Midwestern United States. Avian Disease 41:171-180.

Miller, M. R., AND D. C. DunCAN. 1999. Northern Pintail in North America: Status and conservation needs of a struggling population. Wildlife Society Bulletin 27:788-800.

Miller, M. W., E. S. Williams, C. W. McCarty, T. R. Spraker, T. J. Kreeger, C. T. Larsen, AND E. T. THORNE. 2000. Epizootiology of chronic wasting disease in free-ranging cervids in Colorado and Wyoming. Journal of Wildlife Diseases 36:676690.

Montgomery, R. D., G. Stein, JR., V. D. Stotts, AND F. H. SettLe. 1980. The 1978 epornitic of avian cholera on the Chesapeake Bay. Avian Diseases 24:966-978.

MORSE, S. S. 1993. Examining the origins of emerging viruses. Pages 10-28 in Emerging Viruses (S. S. Morse, Ed.). Oxford University Press, New York.

MORSE, S. S. 1995. Factors in the emergence of infectious diseases. Emerging Infectious Diseases 1: $7-15$.

MurPhy, F. A., AND N. NAthAnSON. 1994. The emergence of new virus diseases: An overview. Seminars in Virology 5:87-102.

National Wildlife Health Center. 2001. Epizootiologal Database. Madison, Wisconsin.

Nichol, S. T., C. F. Spiropoulou, S. MonZunOV, P. E. Rollin, T. G. KsiazeK, H. Feldmann, A. SaNCHeZ, J. Childs, S. ZaKi, AND C. J. Peters. 1993. Genetic identification of a Hantavirus associated with an outbreak of acute respiratory illness. Science 262:914-917.

Nolan, P. M., G. E. Hill, AND M. Stoehr. 1998. Sex, size and plumage redness predict House Finch survival in an epidemic. Proceedings of the Royal Society of London, Series B 265:961-965.

POTERA, C. 1997. Fishing for answers to whirling disease. Science 278:225-226.

PrICE, P. W. 1980. Evolutionary Biology of Parasites. Princeton University Press, Princeton, New Jersey.

PRICE, P. W. 1991. Foreword. Pages v-vii in Bird-parasite Interactions-Ecology, Evolution and Behaviour (J. E. Loye and M. Zuk, Eds.). Oxford University Press, Oxford.

RAhMani, A. R., AND V. PraKash, EDS. 2000. A brief report on the international seminar on vulture situation in India. Bombay Natural History Society, Bombay, India.

ROCKE, T. E., AND M. FRIEND. 1999. Avian botulism. Pages 271-286 in Field Manual of Wildlife Diseases (M. Friend and J. C. Franson, Eds.). U.S Geological Survey, Biological Resources Division, National Wildlife Health Center, Madison, Wisconsin.

Roelke-Parker, M. E., L. Monson, C. Packer, R. Kock, S. Cleaveland, M. Carpenter, S. J. O'BRIEN, A. POSPISCHLl, R. HOFMANN-LeHManN, H. Lutz, G. L. M. Mwamengele, M. N. Mgasa, G. A. Machange, B. A. Summers, And M. J. G. Appel. 1996. A canine distemper virus epidemic in Serengeti lions (Panthera leo). Nature 379:441-445.

Rodger, H. D., AND E. M. Drinan. 1993. Observation of a rickettsia-like organism in Atlantic salmon, Salmo salar L., in Ireland. Journal of Fish Diseases 16:361-369.

RupPRECHT, C. E., AND J. S. SMITH. 1994. Raccoon rabies: The reemergence of an epizootic in a densely populated area. Seminars in Virology 5:155164.

Rupprecht, C. E., J. S. SMith, M. FeKAdu, AND J. E. CHILD. 1995. The ascension of wildlife rabies: A cause for public health concern or intervention? Emerging Infectious Diseases 1:107-114.

SAini, P. K., G. Ransom, and A. M. McNamara. 2000. Emerging public health concern regarding cryptosporidiosis. Journal of American Veterinary Medical Association 217:658-663.

Saltoun, C. A., K. E. Harris, T. L. Mathisen, AND R. PAtTerson. 2000. Hypersensitivity pneumonitis resulting from community exposure to Canada Goose droppings: When an external environmental antigen becomes an indoor environmental antigen. Annals of Allergy, Asthma and Immunology 84:84-86.

SAMUEL, M. D., J. Y. TAKEKAWA, G. SAMELIUS, AND D. R. GOlDberG. 1999. Avian cholera mortality in Lesser Snow Geese nesting on Banks Island, Northwest Territories. Wildlife Society Bulletin 27:780-787.

SANDHU, T. S., AND L. Leibovitz. 1997. Duck virus enteritis (duck plague). Pages 675-683 in Diseases of Poultry, 10th ed. (B. W. Calnek, Ed.). Iowa State University Press, Ames.

Schmitt, S. M., S. D. Fitzgerald, T. M. Cooley, C. S. Bruning-FAnN, L. Sullivan, D. Berry, T. Carlson, R. B. Minnis, J. B. Payeur, AND J. SIKARSKIE. 1997. Bovine tuberculosis in free-ranging white-tailed deer from Michigan. Journal of Wildlife Diseases 33:749-758.

SCHWARTLANDER, B., G. GARNETT, N. WALKER, AND R. ANDERSON. 2000. AIDS in a new millennium. Science 289:64-67.

Siegfried, L. M., AND C. J. BRAND. 1982. A necrotizing enteritis of Canada Geese. Title and Ab- 
stract-Annual Conference, Wildlife Disease Association (Abstract).

Smit, T., A. Eger, J. HaAgsma, AND T. BAKhUizen. 1987. Avian tuberculosis in wild birds in the Netherlands. Journal of Wildlife Diseases 23: 485-487.

SMIth, G. M., AND C. W. CoATES. 1938. Fibro-epithelial growth of the skin in large marine turtles, Chelonia mydas (Linnaeus). Zoologica 23:93-98.

SNYder, S. B., M. J. Richard, R. C. DReWien, N. Thomas, AND J. P. ThiLsted. 1991. Diseases of Whooping Cranes seen during annual migration of the Rocky Mountain flock. Pages 74-80 in Proceedings American Association of Zoo Veterinarians. (R. Junge, Ed.). Media, Pennsylvania.

Spieker, J. O., T. M. Yuill, AND E. C. Burgess. 1996. Virulence of six strains of duck plague virus in eight waterfowl species. Journal of Wildlife Diseases 32:453-460.

Spraker, T. R., M. W. Miller, E. S. Williams, D. H. Getzy, W. J. Adrian, G. G. Schoenveld, R. A. Spowart, K. I. O'ROURKe, J. M. Miller, AND P. A. MERz. 1997. Spongiform encephalopathy in free-ranging mule deer (Odocoileus hemionus), white-tailed deer (Odocoileus virginianus) and Rocky Mountain elk (Cervus elaphus nelsoni) in north central Colorado. Journal of Wildlife Disease 33:1-6.

Steele, K. E., M. J. LinN, R. J. Schoepr, N. Komar, T. W. Geisbert, R. M. Manduca, P. P. Calle, B. L. Raphael, T. L. Clippinger, T. Larsen, J. Smith, R. S. Lanciotti, N. A. Panella, and T. S. MCNAmara. 2000. Pathology of fatal West Nile Virus infections in native and exotic birds during the 1999 outbreak in New York City, New York. Veterinary Pathology 37:208-224.

StONE, R. 2000. Canine virus blamed in Caspian seal deaths. Science 289:2017-2018.

Thomas, N. J., AND R. A. COLE. 1996. The risk of disease and threats to the wild population. Endangered Species Update 13:23-27.

Thomas, N. J., L. H. Creekmore, R. A. Cole, and C. U. Meteyer. 1998. Emerging diseases in southern sea otters. Page 613 in Status and Trends of the Nation's Biological Resources (M. J. Mac, P. A. Opler, C. E. Pucket-Haecker, and P. D. Doran, Eds.). U.S. Geological Survey, Biological Resources Division, Reston, Virginia.

Thomas, N. J., D. Pappagianis, L. H. Creekmore, AND R. M. DunCAN. 1996. Coccidioidomycosis in southern sea otters. Pages 168-173 in Proceeding Fifth International Conference on Coccidioidomycosis (H. E. Einstein and A. Catanzaro, Eds.). National Foundation for Infectious Diseases, Washington, D.C.
TOFT, C. A. 1991. Current theory of host-parasite interactions. Pages 3-15 in Bird-Parasite Interactions-Ecology, Evolution and Behaviour (J. E. Loye and M. Zuk, Eds.). Oxford University Press, Oxford.

VAN Riper III, C., S. G. VAN RIPER, M. L. GOLF, AND M. LAIRD. 1986. The epizootiology and ecological significance of malaria in Hawaiian land birds. Ecological Monographs 56:327-344.

VARGAS, H. 2000. News and announcements. Ornithological Newsletter 138:2.

VitouseK, P. M., H. A. MoOney, J. LubChenco, AND J. M. Melillo. 1997. Human domination of Earth's ecosystems. Science 277:494-499.

WALKer, D. H., AND J. S. DuMIER. 1996. Emergence of ehrlichioses as human problems. Emerging Infectious Diseases 2:18-29.

WARNER, R. E. 1968. The role of introduced diseases in the extinction of the endemic Hawaiian avifauna. Condor 70:101-120.

Wildlife Management Institute. 1970. Fowl cholera in Maryland took toll. Outdoor News Bulletin 24:6.

Wilkins, K. A., AND E. G. CoOCH. 1999. Waterfowl Population Status, 1999. U.S. Department of Interior, Fish and Wildlife Service, Washington, D.C.

Williams, E. S., AND S. Young. 1982. Spongiform encephalopathy of Rocky Mountain elk. Journal of Wildlife Diseases 18:465-471.

WiLsON, M. E. 1995. Travel and the emergence of infectious diseases. Emerging Infectious Diseases 1:39-46.

Windingstad, R. M., R. J. Cole, P. E. Nelson, T. J. Roffe, R. R. George, AND J. N. Dorner. 1989. Fusarium mycotoxins from peanuts suspected as a cause of Sandhill Crane mortality. Journal of Wildlife Diseases 25:38-46.

Windingstad, R., D. Docherty, and N. Thomas. 1993. Pox Infections in Bald Eagles. Research Information Bulletin 25, U.S. Fish and Wildlife Service, Washington D.C.

Wobeser, G. F., F. A. Leighton, R. Norman, D. J. Meyers, D. Onderka, M. J. Pybus, J. L. Neufeld, G. A. FoX, AND D. J. AleXANDER. 1993. Newcastle disease in wild water birds in western Canada, 1990. Canada Veterinary Journal 34:353359.

WoBESER, G., AND D. J. RAINNIE. 1987. Epizootic necrotic enteritis in wild geese. Journal of Wildlife Diseases 23:276-385.

Woods, L. W., P. K. Swift, B. C. BARR, M. C. HorZiNeK, R. W. Nordhausen, M. H. Stillian, J. F. Patton, M. N. Oliver, K. R. Jones, and N. J. MACLACHLAN. 1996. Systemic adenovirus infection associated with high mortality in mule deer (Odocoileus hemionus) in California. Veterinary Pathology 33:125-132. 